\title{
EDUCATIONAL ROBOTICS AS A MEANS OF DEVELOPING PUPILS' AND STUDENTS' COMPUTATIONAL THINKING
}

\section{${ }^{a}$ LUCIE BRYNDOVÁ, ${ }^{b}$ MILAN KLEMENT}

Palacký University of Olomouc, Faculty of Education, Žižkovo nám. č. 5, Olomouc, 771 40, Czech Republic email: ${ }^{a}$ lucie.bryndova01@upol.cz, ${ }^{b}$ milan.klement@upol.cz

This paper was supported by the project IGA_PdF_2021_018 "Standardization and evaluation of an assessment tool for measuring the level of development of computational thinking in primary school pupils". Abstract: The accelerating development of technology over the past decades has brought many radical changes in all aspects of life and has unquestionably affected the functioning of our society. The expansion of the digital space and the technological innovation in industry, commerce and household have given rise to a large number of new concepts relating to digital and information technology and their use. In the context of supporting these activities and needs, the FEP document has been updated for the educational area Information and Communication Technology in elementary schools but also in general and technical secondary schools. This innovation is built primarily on the development of computational thinking, which is based on two pillars - algorithmization/programming and educational robotics.

The present paper uses educational research to analyse the area of educational robotics as one of the important tools for promoting the concept of developing computational thinking including a description of the specific tools for the implementation of this type of teaching. The aim of the research study was to analyse the current level of pupils' awareness of and practical experience with educational robotics, both in school and in extracurricular activities. The research tool for data collection was an online questionnaire designed by the authors.

Keywords: Teaching computer science, computational thinking, educational robotics, educational robotics tools.

\section{Introduction}

The development and implementation of the concept of integrating pupils' computational thinking into the curriculum of computer science subjects is currently one of the major challenges of education systems in many countries (Wing, 2014). In a simplified way, digital education responds to the changes in society related to the development of digital technology and their use in various areas of human activity (e.g., Klement et al., 2020, Tang et al, 2020, Román-Gonzáles at al., 2018, Brennan, Resnick, 2013, CSTA \& ISTE, 2011, etc.) It includes both education that effectively uses digital technology to support teaching and learning and education that develops pupils' digital literacy and prepares them for life in society and the labour market where the requirements for the knowledge and skills in the information technology segment are growing (Tran, 2017).

This suggests that computational thinking includes information science and uses its knowledge, concepts and fundamental principles. At the same time, it can use programming as a tool but is not dependent on these concepts (Balanskat, 2018, Angeli et al., 2016, Bocconi et al. 2016). The approach that does not make a direct link between computational thinking and the ability to use a specific programming language is the reason for a schism at an academic, legislative and educational level. Some national curricula follow the concept of computational thinking independent of formal programming languages, while others refer to a direct need of programming within the basic definition of the concept (Balanskat, 2018). This framework is the basis for the overall implementation of CT (Computational Thinking) into the curriculum. Each definition of the concept of CT and its area needs to consider the national context (Klement, 2018).

From a didactic and teaching point of view, an important aspect in the development of CT is the practical application of its concepts including algorithmization, decomposition, generalization, evaluation and abstraction (Angeli et al., 2016). If the aim of the revision of the curricula and the development of computational thinking in schools is to train the students in the use of information technology in their lives and on the labour market, it is crucial that they are able to use their skills and abilities. Programming plays an essential role in the practical implementation of the development of computational thinking. According to a study that analysed the upcoming curricular revisions in the area of information science and computational thinking in European countries, thirteen of the countries involved in the research focused their revisions primarily on the development of pupils' skills in problem-solving as well as critical and logical thinking. In the context of this objective, seven of these countries focused especially on the introduction of programming. Seven other countries only extended the already established system of teaching programming to include the concepts of CT development (Bocconi et al. 2016).

\section{The sub-areas of computational thinking}

Since the beginning of the international debate on the integration of computational thinking in the system of education, there have been attempts to define the specific sub-areas of CT. The primary objective of this process is to concretize the very general definition of the phenomenon of computational thinking which is not suitable for a practical implementation of CT in the school system (Román-González et al., 2017). At present, most national curricular definitions of the concept of computational thinking are based on or largely match the definitions of the characteristics and abilities related to the use of CT according to CSTA and ISTE in 2011. In 2006, the CSTA and ISTE document identified six areas for the K-12 Curriculum, which complements but is not limited to the process of computational thinking, and additional six abilities and skills linked with the concept of CT. Therefore, this definition is based on similarities, skills and approaches that the individual who uses computational thinking should have. Specifically, this includes the abilities of formulation of a machine solution, data handling, data representation by means of abstractions including models and simulations, automation and algorithms, searching for an optimal solution and the application of the problem-solving process to similar problems. Five years later this document was updated in order to emphasise the components of abstraction, automation and analysis (CSTA and ISTE 2011).

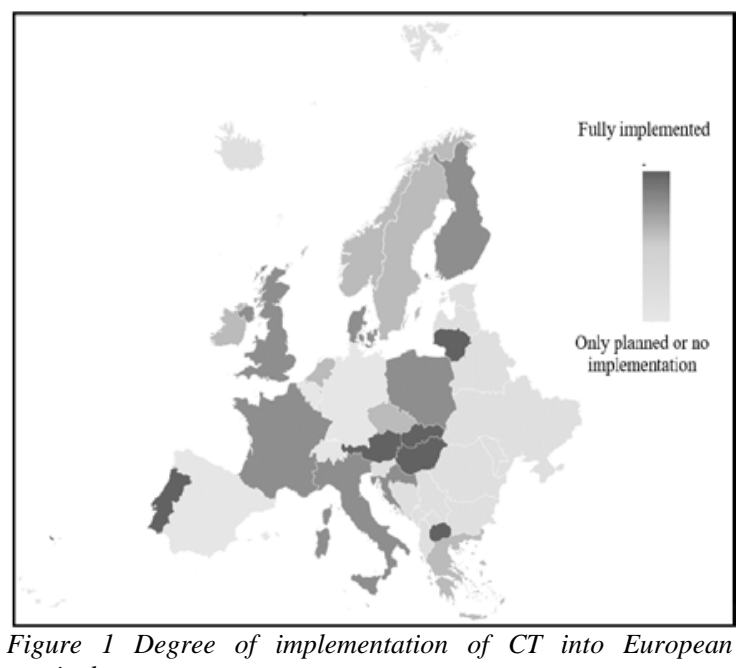
curricula

Later, many authors tried to simplify and reduce these definitions to the basic elements that would describe the essence of the original definitions. Likewise, for educational and didactic purposes the concretization of the areas that define CT is usually carried out by means of a detailed analysis of the CSTA \& ISTE document. The following comparative Table 1 shows the subcomponents of computational thinking as defined by CSTA \& ISTE and the keywords and phrases included in this definition, which the authors of the present paper used to define the corresponding CT skills (Angeli et al., 2020, Bocconi et al., 2016, Wing 2014, Selby, 2012) linked with these concepts that pupils who want to use computational thinking should adopt. 
Table 1 Definitions of the areas for the development of computational thinking

\begin{tabular}{|c|c|c|}
\hline $\begin{array}{c}\text { Original definition by CSTA } \\
\text { \& ISTE }\end{array}$ & Keyword & Corresponding CT skill \\
\hline $\begin{array}{c}\text { Problem formulation for } \\
\text { machine solution }\end{array}$ & Formulation & Syntax, programming \\
\hline $\begin{array}{c}\text { Organize and analyse data in } \\
\text { a logical way }\end{array}$ & Data & Data processing \\
\hline $\begin{array}{c}\text { Represent data using } \\
\text { bbstractions }\end{array}$ & Representation & Modelling \\
\hline $\begin{array}{c}\text { Thinking automation using } \\
\text { algorithmic thinking }\end{array}$ & $\begin{array}{c}\text { Algorithmic } \\
\text { thinking }\end{array}$ & $\begin{array}{c}\text { Algorithmization, } \\
\text { automation }\end{array}$ \\
\hline $\begin{array}{c}\text { Analysis of possible solutions } \\
\text { to achieve the most effective } \\
\text { combination }\end{array}$ & $\begin{array}{c}\text { The most effective } \\
\text { combination }\end{array}$ & $\begin{array}{c}\text { Abstraction, } \\
\text { optimization }\end{array}$ \\
\hline $\begin{array}{c}\text { Generalization and } \\
\text { application of a specific } \\
\text { problem-solving process }\end{array}$ & Generalization & $\begin{array}{c}\text { Evaluation, debugging, } \\
\text { generalization }\end{array}$ \\
\hline
\end{tabular}

Although the current approaches to CT considerably vary, a review of the relevant literature and documents suggests that most of the proposed sub-components match in the areas of algorithmization, abstraction, debugging or evaluation, decomposition and generalization (Balanskat, 2017, Bocconi et al., 2016). At the curricular level, any changes to these areas are governed by the specific national concepts of computational thinking (So et al., 2020, Sengupta et al., 2013, etc.)

3 Educational robotics as a supportive tool in teaching focused on the development of computational thinking

One of the most promising educational tools in the development of computational thinking and programming and at the same time a highly valued subject that supports the modernization of the teaching process is educational robotics. Specialized propaedeutic robots and programmable kits are currently proven and very attractive teaching tools. They are extremely effective not only in catching the pupils' interest but they are also an indispensable aid for the visualization of the learning content. For the development of CT in schools, many authors emphasise the use of age-appropriate and specialized learning aids and programming environments such as Scratch, Kodu, Etoys, Ozzobot and Lego We-Do (Tran, 2017). Typically, educational robotics is specifically designed for the needs of schools and focuses on the education of pupils of a specific category and their development in the field of algorithmization, programming, technical thinking, mathematical and geometrical knowledge or the development of creativity. The following table shows the most frequent propaedeutic robots used in primary education and the corresponding programming languages.

Table 2 Propaedeutic robotics and programming languages

\begin{tabular}{|c|c|c|}
\hline Robotic kit & $\begin{array}{c}\text { Supported programming } \\
\text { language }\end{array}$ & Default language type \\
\hline $\begin{array}{c}\text { LEGO Mindstorms } \\
\text { ev3 }\end{array}$ & $\begin{array}{c}\text { RCX Code, C/C++, Java, } \\
\text { Visual Basic, Scratch, etc. }\end{array}$ & Text block language \\
\hline LEGO WeDo 2.0 & $\begin{array}{c}\text { Own iconic language, } \\
\text { Scratch }\end{array}$ & ICONIC block language \\
\hline Ozobot EVO, Bit & OzoBlockly & Text block language \\
\hline Arduino & C/C++, Scratch & $\begin{array}{c}\text { Multiparadigmatic } \\
\text { programming language }\end{array}$ \\
\hline mBot & mBlock, C++ & Text block language \\
\hline BBC micro:bit & $\begin{array}{c}\text { MakeCode, Scratch, } \\
\text { Python, JavaScript }\end{array}$ & Text block language \\
\hline
\end{tabular}

Most of these educational robots are designed for elementary school pupils and use visual programming languages including text blocks or iconic blocks. This programming method typically uses commands in the form of pre-set blocks that pupils arrange in a programming sequence on the drag and drop principle. This programming method is ideal for beginners due to its simplicity and clarity. Visual programming is also used in didactic games for the teaching of programming and algorithmization.

\section{The tools for the implementation of educational robotics}

It has been confirmed that educational robotics has an indisputable positive effect on the development of pupils in the field of CT and programming. At the same time, the application of educational robotics as a supportive teaching tool has been demonstrated to minimize pupils' gender differences in their approaches to programming as well as their performance (Rubio et al., 2015). A disadvantage of educational robotics may be the fact that it is relatively expensive and the acquisition costs might often be too high for the schools. Therefore, in the selection of an appropriate educational robotics tool, care should be taken to choose a tool that provides the broadest possible degree of application for a reasonable price.

The following text analyses available products that can be used for the purposes of educational robotics, particularly in terms of their didactic applicability at the different levels of education. This is due to the fact that in the development of CT in schools a number of authors emphasise the use of age-appropriate and specialized learning aids and programming environments.

Table 3 Specific tools for the implementation of educational robotics teaching

\begin{tabular}{|c|c|c|c|}
\hline Stage & Tool & Tool description & Tool example \\
\hline $\begin{array}{l}\text { Nursery } \\
\text { schools }\end{array}$ & Bee-Bot & $\begin{array}{l}\text { Robotic bees, also used } \\
\text { with different pads. } \\
\text { Using the buttons on the } \\
\text { back of the bee, pupils } \\
\text { programme the bee and } \\
\text { basically create a } \\
\text { sequence of steps } \\
\text { (algorithm) that the bee } \\
\text { then executes. }\end{array}$ & \\
\hline $\begin{array}{c}\text { Primary } \\
\text { schools } \\
{\text { (stage } 1)^{1}}^{1}\end{array}$ & $\begin{array}{l}\text { LEGO } \\
\text { WeDo }\end{array}$ & $\begin{array}{l}\text { Using the LEGO }{ }^{\circledR} \\
\text { WeDo } 2.0 \text { robotic kit. } \\
\text { Pupils build a LEGO } \\
\text { robot, create an } \\
\text { algorithm in a graphic } \\
\text { programming } \\
\text { environment and in this } \\
\text { way programme the } \\
\text { robot. This develops not } \\
\text { only their algorithmic } \\
\text { thinking but also } \\
\text { creativity an and } \\
\text { engineering skills. }\end{array}$ & \\
\hline $\begin{array}{l}\text { Lower } \\
\text { secondary } \\
\text { schools } \\
\text { (stage 2)* }\end{array}$ & $\begin{array}{c}\text { LEGO } \\
\text { Mindstorms }\end{array}$ & $\begin{array}{l}\text { Using the LEGO } \\
\text { Mindstorms Education } \\
\text { EV3 robotic kit. Previous } \\
\text { experience with Scratch } \\
\text { visual programming } \\
\text { language } \\
\text { recommended. The } \\
\text { principle is similar to that } \\
\text { of LEGO WeDo but this } \\
\text { kit is more difficult and } \\
\text { offers more possibilities } \\
\text { in terms of construction } \\
\text { and programming. }\end{array}$ & of \\
\hline $\begin{array}{l}\text { Secondary } \\
\text { schools } \\
\text { (non- } \\
\text { technical) }\end{array}$ & Micro:Bit & $\begin{array}{l}\text { Micro:bit is an open- } \\
\text { source development kit } \\
\text { developed in the UK and } \\
\text { supported by the BBC. It } \\
\text { is primarily intended for } \\
\text { the teaching of } \\
\text { information technology. } \\
\text { It contains a } 5 \times 5 \text { LED } \\
\text { matrix and two } \\
\text { programmable buttons, } \\
\text { compass, triaxial } \\
\text { accelerometer } \\
\text { (gyroscope), etc. }\end{array}$ & $=$ \\
\hline $\begin{array}{l}\text { Secondary } \\
\text { schools } \\
\text { (technical) }\end{array}$ & Arduino & $\begin{array}{l}\text { Arduino is a prototype } \\
\text { and open platform based } \\
\text { on easy-to-use hardware } \\
\text { and software. The } \\
\text { Arduino programmable } \\
\text { boards process inputs } \\
\text { and use a programme } \\
\text { code to create an output. } \\
\text { The Arduino board can } \\
\text { be connected to a number } \\
\text { of hardware components. } \\
\text { Using open-source } \\
\text { libraries available on the } \\
\text { internet, Arduino can be } \\
\text { used for a wide spectrum } \\
\text { of projects ranging from } \\
\text { extremely simple to } \\
\text { highly complex ones. }\end{array}$ & $=$ \\
\hline
\end{tabular}

Those schools for which educational robotics is unaffordable can use low-cost or free alternative tools suitable for the development of computational thinking and programming skills.

\footnotetext{
${ }^{1} *$ In the Czech Republic, there are two levels of elementary education-primary and lower secondary. The primary level includes grades one to five (children aged six to lower secondary. The primary level includes grades one to five (children aged six to eleven years), while the lower secondary level includes grades six to nine (children
aged twelve to fifteen years).
} 
There are currently many specialized free-of-charge and freely available online tools and methodologies for the teaching of programming and computational thinking. However, their description would exceed the permissible extent of this paper. Therefore, this will be included in other papers that we are currently working on.

\section{Educational robotics from the perspective of elementary school pupils - a research probe}

As mentioned above, there are a number of tools on the market for the implementation of educational robotics. Educational robotics has also become one of the important components for the development of the concept of computational thinking in terms of the binding curricular documents. During the two-year transition period this content will also be implemented in the relevant educational documents and should then be delivered in schools. However, a question arises as to whether pupils and teachers are prepared for this type of education and whether they have any previous experience with educational robotics tools, for example in the form of robotic kits. In order to answer this question in a satisfactory way, we have conducted a research study focusing on the practical experience of pupils in lower secondary schools with robotic kits.

The aim of the research study was to analyse the current level of pupils' awareness of and practical experience with educational robotics, both in school and in extracurricular activities. The research tool for data collection was an online questionnaire designed by the authors. This choice was based on the need to address the pupils in selected elementary schools at a time of restricted contact caused by the Covid-19 pandemic. For this reason, the use of an electronic questionnaire was considered as the most appropriate method due to electronic distribution, completion and evaluation.

The questionnaire was designed according to the basic requirements and qualities as specified by Chráska (2016, pp. 164-165). The questionnaire was distributed via e-mail, which in addition to a cover letter included a link which the respondents used to access the questionnaire. The e-mails were sent to computer science teachers or their deputies asking them to complete the questionnaire or forward it to their pupils who were likely to have a positive attitude to computer science (e.g., pupils of mathematics, physics, chemistry, computer science and technical education). The completion of the questionnaire was entirely anonymous. If any respondent was interested in the outcomes of the study, they had the opportunity to leave their e-mail address at the end of the questionnaire. Most of the questions were mandatory which means that the respondents had to enter an answer in order to proceed in the questionnaire. Some of the questions had only one possible answer, while others had multiple correct answers or provided space for a free answer. The questionnaire also included questions identified as optional where the respondents gave their responses only if they were able to answer.

The questionnaire survey was conducted from November 2020 to January 2021 and was completed by a total of 135 respondents-pupils in lower secondary schools. This was followed a period of processing and evaluation of the responses.

Table 4 Structure of the research sample

\begin{tabular}{|c|c|c|c|}
\hline Attribute & Group & Number & Percentage \\
\hline \multirow{3}{*}{ Gender } & Girls & 81 & $60.0 \%$ \\
\cline { 2 - 4 } & Boys & 54 & $40.0 \%$ \\
\hline \multirow{3}{*}{ Grade } & 6 & 26 & $19.3 \%$ \\
\cline { 2 - 4 } & 7 & 47 & $34.8 \%$ \\
\cline { 2 - 4 } & 8 & 37 & $27.4 \%$ \\
\hline \multirow{3}{*}{ School location } & 9 & 25 & $18.5 \%$ \\
\cline { 2 - 4 } & Urban & 78 & $57.8 \%$ \\
\cline { 2 - 4 } & Rural & 57 & $42.2 \%$ \\
\hline
\end{tabular}

\section{Selected results of the research study}

One of the research areas was pupils' interest in the relatively unknown thematic unit aimed at educational robotics in elementary schools. The objective was to identify the degree of interest among elementary school pupils in this thematic unit as one of the important factors for the development of computational and technical thinking and its implementation in classes, educational environment and life of the school.

In many schools, educational robotics is not very popular. If educational robotics is used in classes, it usually oscillates between two poles. The first pole is the use of educational programming languages and developmental environments such as Lego or Arduino. The other pole is represented by "real" programming or scripting languages and devices such as H\&S electronic systems and VEX Robotics that allow the development of production applications. For many years, the professional community has been involved in a debate on the two poles; one group emphasise the need for a didactic approach to educational robotics, while the advocates of the other pole support "real" solutions in the teaching process which pupils will use in life or in their later academic career. Although it is not the responsibility of pupils to determine the learning content and its focus, their opinions and preferences during the implementation of this educational concept are a crucial factor that may affect future outcomes and benefits.

For this reason, we focused on an analysis of pupils' interest in educational robotics using the following two questionnaire items: "Do you know any robotic kits?" and "Do you own any robotic kits?” The set of questionnaire items was used to identify the current level of interest in the education of this thematic unit and pupils' ideas about possible future application of the knowledge and skills because without a clear idea concerning the applicability of the knowledge it is extremely difficult to motivate learners. This concept was used to determine the following research assumption: Elementary school pupils are interested in the thematic unit focused on educational robotics.

The responses of lower secondary school pupils are summarized in Figures 2 and 3. The responses were also used to test the research assumption. The figure show cumulative numbers as the respondents could give multiple answers or provide their own answers.

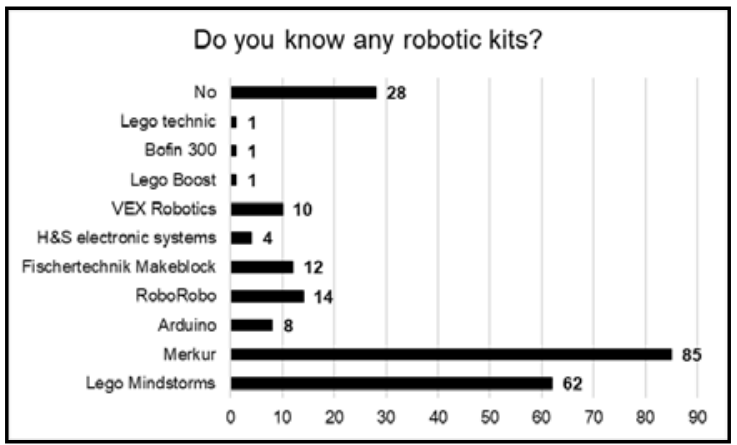

Figure 2 Knowledge of elementary school pupils in the area of robotic kits

The results shown in Figure 2 suggest that most elementary school pupils are familiar with the Merkur robotic kit (37.6 \%) and Lego Mindstorms (27.4 \%). This result is not surprising because both are widely used and commercially available construction kits with a long tradition (Merkur in particular is very popular in the Czech Republic). For completeness, only $12.4 \%$ of pupils suggested that they did not know any robotic kit, which is considered a positive result. 


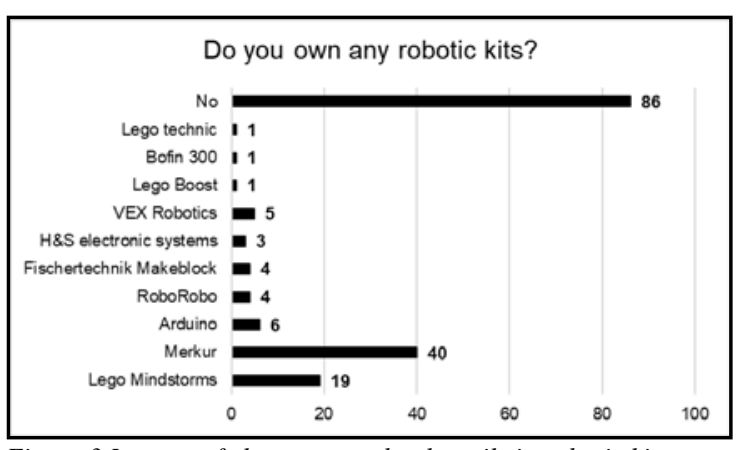

Figure 3 Interest of elementary school pupils in robotic kits

Although the ownership of a particular robotic kit need not always indicate a clear interest, it may suggest a certain liking during pupils' extracurricular activities. An analysis of the results shown in Figure 3 suggests that almost half of pupils (49.4\%) declare the ownership of a robotic kit. The most popular robotic kits are again Merkur (23.5 \%) and Lego Mindstorms (11.2 \%). This is again considered a positive result because it points to a relatively high degree of pupils' interest in this area. At the same time, this result confirms the research assumption.

At present, there is a significant gender imbalance among professional programmers. Although this trend is known around the world, the reasons why more men than women look for jobs in the computer science sector is unknown. Many research studies refer to problems with women's self-confidence in programming (Rubio et al., 2015). Similar tendencies are also observed among elementary school pupils. Male pupils are often more self-confident in their abilities to learn programming compared with their female counterparts (Cheng, 2019). Nevertheless, most research studies confirm that programming skills and study capabilities in computer science do not differ between boys and girls. The only difference is their approach and motivations to programming, in which girls show a tendency to undervalue their own skills in the field of computer science.

In order to confirm or disprove this tendency in the context of educational robotics, we have included items in the questionnaire that could be used to assess this alleged gender imbalance. The items were as follows: "Do you work with a robotic kit in your free time?" and "Do you attend a club aimed at robotics or robotic kits?". The design of these questionnaire items made it possible to use the Student's t-test. These items were deliberately not directed at institutional education, where certain gender stereotypes could be expected, but rather at the area of extracurricular education and interest activities. On the basis of the above, the following research hypothesis $(\mathrm{H})$, null hypothesis $\left(\mathrm{H}_{0}\right)$ and alternative hypothesis $\left(\mathrm{H}_{\mathrm{A}}\right)$ were formulated.

The hypothesis was tested on a sample of 135 respondentsboys and girls from lower secondary schools-using the Student's t-test for independent groups with gender as the grouping variable as shown in Table 5.

Table 5 The declared degree of interest in educational robotics by gender

\begin{tabular}{|c|c|c|c|c|c|c|c|}
\hline \multirow{2}{*}{ Statement } & $\begin{array}{c}\text { Group 1 } \\
\text { Girls }\end{array}$ & $\begin{array}{c}\text { Group 2 } \\
\text { Boys }\end{array}$ & p & $\begin{array}{c}\text { Valid } \\
\text { responses } \\
\text { Group 1 }\end{array}$ & $\begin{array}{c}\text { Valid } \\
\text { responses } \\
\text { Group 2 }\end{array}$ & $\begin{array}{c}\text { Stand. } \\
\text { deviation } \\
\text { Group 1 }\end{array}$ & $\begin{array}{c}\text { Stand. } \\
\text { deviation } \\
\text { Group 2 }\end{array}$ \\
\hline $\begin{array}{c}\text { Do you } \\
\text { work with } \\
\text { a robotic } \\
\text { kit in your } \\
\text { free time? }\end{array}$ & 1.914141 & 2.006944 & 0.314445 & 81 & 54 & 0.853599 & 0.823573 \\
\hline $\begin{array}{c}\text { Do you } \\
\text { attend a } \\
\text { club aimed } \\
\text { at } \\
\text { robotics? }\end{array}$ & 3.419192 & 3.333333 & 0.305268 & 81 & 54 & 0.698828 & 0.844563 \\
\hline
\end{tabular}

Given that $\mathrm{p}>0.05$ was achieved for both monitored quantities, at the determined level of probability the null hypothesis can be rejected and the alternative hypothesis accepted. Therefore, with a high degree of probability it can be concluded that there are no differences between the declared degree of interest in educational robotics between boys and girls from elementary schools.

The last part of the research presented in this paper focused on the frequency of inclusion of educational robotics in the context of institutional education in schools. In order to identify this fact, the questionnaire included the following item: "Have you ever seen a robot/robotic kit being used as a teaching aid in your school?" The aim of this item was to identify whether and in which subjects pupils had encountered educational robotics in their school. Although this area is already included in the FEP Curriculum in the area Information and Communication Technology and there are relevant educational resources (e.g., www.imysleni.cz), it is still a relatively new area and both schools and their teachers now have a two-year transitional period during which they will implement this content in the system of education. This concept was used to determine the following research assumption: At the moment, elementary school pupils do not have the opportunity to take part in education aimed at educational robotics.

The responses of pupils from lower secondary schools are summarized in Figure 4. The responses were also used to test the research assumption. The figure again shows cumulative numbers as the respondents could give multiple answers or provide their own answers.

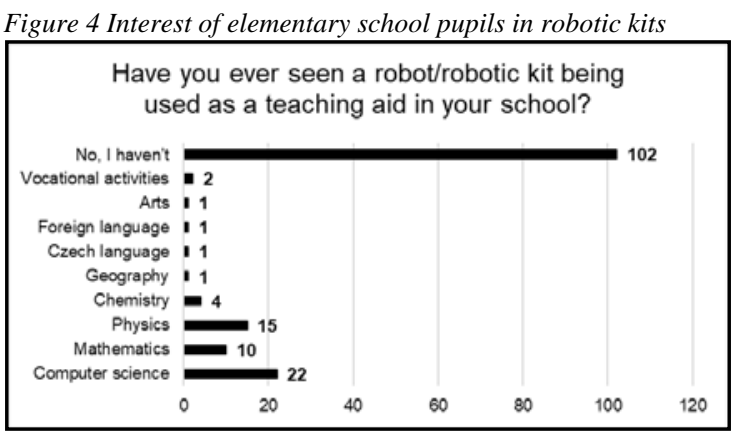

An analysis of the results shown in Figure 4 suggests that the majority of pupils (64.2 \%) have so far not encountered educational robotics in the course of their school education. Those who have encountered educational robotics as part of their education mentioned the following subjects: Computer science (13.8\%), Physics (9.4\%) and Mathematics (6.3\%). This is not considered a positive result because it points to an incomplete achievement of the innovated Computer Science FEP Curriculum. However, this result confirms the research assumption.

\section{Discussion}

According to the Digital Education Strategy Until 2020, schools, teachers and primarily pupils should be provided with new opportunities. A major change to the elementary and secondary school curriculum has been made in order to respond to the current trends and to capture the current needs in education, preparation and subsequent integration of graduates of technical fields in the work process. However, the changes are gradual and until their full integration schools have to tackle the current unsatisfactory situation.

The aim of the present research was to analyse the current state during the ongoing implementation of the curricular reform in a very narrow area of educational robotics and to map and highlight the weaknesses that require attention. The results show that educational robotics is gradually finding its way to Czech schools but so far this journey has been difficult. From the schools' perspective, one of the main problems is finance. Robotic kits are either unaffordable or schools can only purchase a limited number of them which makes teaching difficult. 
Another problem is the subsequent process of integration in the education process. The most common and the simplest solution is the establishment of leisure clubs but these clubs include only a limited number of pupils. Another option is the introduction of a core elective subject but its capacity is often limited. Integration in other subjects is difficult as the time for educational robotics is significantly limited due to the absence of a suitable thematic unit in the curriculum. Teachers themselves face problems with insufficient awareness and lack information about new teaching aids. If they decide to use these teaching aids, they often have to rely on resources available free of charge due to financial reasons. Fortunately, there has been a positive shift in this area as teachers were provided with methodological support through the PRIM project (promoting the development of computational thinking). The project involved all faculties of education in the Czech Republic and the objective was to change the orientation of the computer science subject.

However, strengthening the position of computer science subjects in the curriculum is not the end of the process. The results suggest that there is a persisting problem with a large number of unqualified teachers of computer science, which is one of the most suitable subjects for educational robotics. The situation also needs to be improved in the context of teacher training and provision of adequate conditions and background in the area of computer science education.

\section{Conclusion}

The current trend of implementing computational thinking in national curricula is necessary to modernize the educational systems of developed countries in response to the accelerating technology and the labour market. In many countries, this implementation is linked to the long-announced integration of programming in the national curricula or extends the already established tradition of this type of teaching. The purpose of this modernization is to ensure the equality of elementary education in the field of computer science, which in the past had been left to leisure activities or optional subjects and computer literacy had not been developed across the whole population.

As far as the development of computational thinking in schools is concerned, the greatest benefit is the education of the general population in the area of programming as well as the principles of functioning of modern technology, easier adaptation to emerging new technology as well as the promotion of its creative use at work and in everyday life. Although the concept of computational thinking is not necessarily linked to programming, in the practical implementation of its development in the teaching process, programming is recommended. This practical implementation could use specialized learning aids and tools including propaedeutic programming environments and educational robotics.

The research study, the purpose of which was to analyse the current level of pupils' awareness of and practical experience with educational robotics both in school and in extracurricular activities suggested several conclusions and recommendations. An important conclusion is that educational robotics is perceived positively by pupils and both boys and girls are interested in this area. We have also managed to disprove one of the frequent prejudices concerning gender imbalance in the field of computer science. It has been confirmed that gender does not determine the interest in educational robotics. This learning content is received in the same way by both boys and girls. A little disturbing is the fact that the majority of elementary school pupils have not encountered educational robotics and we believe there are great reserves and challenges that will have to be addressed in both research and practice.

\section{Literature:}

1. Angeli, Ch., Valanides, N. Developing young children's computational thinking with educational robotics: An interaction effect between gender and scaffolding strategy. Computers in Human Behavior. 2020, DOI: 10.1016/j.chb.2019.03.018. 2. Angeli, C., Voogt, J., Fluck, A., Webb, M., Cox, M., MalynSmith, J., Zagami, J. A. Computational Thinking Curriculum Framework: Implications for Teacher Knowledge. Educational Technology \& Society, 2016, 19(3).

3. Balanskat, A., Engelhardt, K., Ferrari, A., 'The integration of Computational Thinking (CT) across school curricula in Europe', European Schoolnet Perspective, Eds. 2, 2017.

4. Balanskat, A., Engelhardt, K., Licht, A. H., Strategies to include computational thinking in school curricula in Norway and Sweden- European Schoolnet's 2018 Study Visit. European Schoolnet, Brussels, 2018.

5. Bocconi, S., Chioccariello, A., Dettori, G., Ferrari, A., Engelhardt, K. Developing computational thinking in compulsory education - Implications for policy and practice, 2016.

6. Brennan, K., Resnick, M. New frameworks for studying and assessing the development of computational thinking. In Proceedings of the 2012 Annual Meeting of the American Educational Research Association, Vancouver, Canada, 2012.

7. Chráska, M. Metody pedagogického výzkumu: základy kvantitativního výzkumu. 2nd updated edition. Praha: Grada, 2016. Pedagogika (Grada). ISBN 978-802-4753-263.

8. CSTA \& ISTE. Operational Definition of Computational Thinking for K-12 Education. 2011.

9. Klement, M. Traditional topics for the framework educational programme focused on ICT area, and the perception of these topics by the primary school ninth grade pupils. Journal of Technology and Information Education, 2018, 10(1), 43-62.

10. Klement, M., Dragon, T., Bryndová, L. Computational Thinking and How to Develop it in the Educational Process. 1st ed., Olomouc, Vydavatelství UP, 2020, 216 p. ISBN 978-80244-5796-3. DOI: 10.5507/pdf.20.24457963.

11. MŠMT. (2017). Rámcový vzdělávaci program pro základní vzdélávání. Praha.

12. Román-Gonzáles, M., Pérez-González, J.-C., JiménezFernández, C. Which cognitive abilities underlie computational thinking? Criterion validity of the Computational Thinking Test. Computers in Human Behavior, 72(2017), 678-691.

13. Rubio, M. A., Romero-Zaliz, R., Mañoso, C., De Madrid, A. P. Closing the gender gap in an introductory programming course. Computers \& Education, 2015, 82, 409-420.

14. Sengupta, P., Kinnebrew, J. S., Basu, S., Biswas, G., Clark, D. Integrating computational thinking with K-12 science education using agent-based computation: A theoretical framework. Education and Information Technologies. 2013, 18(2), 351-380. DOI: 10.1007/s10639-012-9240-x.

15. So, H., Jong, M. S., Liu, C. Computational Thinking Education in the Asian Pacific Region. Asia-Pacific Edu Res 29, pp. 1-8 (2020). https://doi.org/10.1007/s40299-01900494-w.

16. Tang, X., Yin, Y., Lin, Q., Hadad, R., Zhai, X. Assessing computational thinking: A systematic review of empirical studies. Computers \& Education. 2020, 148 DOI: 10.1016/j.compedu.2019.103798. ISSN 03601315.

17. Tran, Y. Computational Thinking Equity in Elementary Classrooms: What Third-Grade Students Know and Can Do. Journal of Educational Computing Research. 2017, 57(1), 3-31. 18. Wing, J. M. Computational thinking benefit society. Social Issues in Computing blog, 2014.

19. Wing, J. M. Computational thinking. Communications of the ACM, 49(3):33-35, 2006.

Primary Paper Section: I

Secondary Paper Section: AM 